\title{
DESKRIPSI SOAL UJIAN NASIONAL MATEMATIKA SMA TAHUN PELAJARAN 2018/2019 BEDASARKAN TAKSONOMI SOLO
}

\author{
Dwi Lestari $^{\left.1^{*}\right)}$, Budiyono(1), Dita Yuzianah ${ }^{1)}$. \\ e-mail:dwi.lestari240198@gmail.com
}

\begin{abstract}
This study aims to describe the level of the national high school science exam questions for the 2018/2019 school year, which is defined based on the SOLO taxonomy and examines what operational verbs are in the subject. This type of research uses descriptive qualitative. The source of this research is the text of the National High School science Mathematics national examination for 2018/2019 academic year. The data collection technique used is the data analysis technique, according to Milles and Huberman. The object retrieval technique used is using a comparative method. The question used in this study were 20 odd number questions on the text of the Mathematics science high school national exam. The results of this study are as follows. The level questions on the national mathematics high school mathematics national exam 2018/2019 includes four levels in the SOLO taxonomy with uni structural breakdown of $5 \%$, multi structural $10 \%$, relational by $75 \%$, and extended abstracts by $10 \%$.
\end{abstract}

Keywords: SOLO taxonomy, national exam.

\begin{abstract}
Abstrak
Penelitian ini bertujuan untuk mendeskripsikan tingkat soal ujian nasional SMA IPA tahun pelajaran 2018/2019 yang dideskripsikan berdasarkan taksonomi SOLO serta mengkaji setiap kata kerja operasional yang apa pada soal tersebut. Jenis penelitian ini menggunakan kualitatis deskriptif. Sumber penelitian ini adalah naskah soal ujian nasional matematika SMA IPA tahun pelajaran 2018/2019. Teknik pengambilan data yang digunakan menggunakan teknik analisis data menurut Milles dan Hubberman, Teknik pengambilan objek yang digunakan menggunakan teknik proposive samplngi. Soal yang digunakan pada penelitian ini adalah 20 soal bernomor ganjil pada naskah soal ujian nasional matematika SMA IPA. Hasil penelitian ini adalah sebagai berikut. Tingkat pertanyaan pada soal ujian nasional matematika SMA IPA tahun pelajaran 2018/2019 memuat ke empat tingkatan pada taksonomi SOLO dengan rincian unistruktural sebesar 5\%, multistruktural sebsar $10 \%$, relasional sebesar $75 \%$, dan abstrak diperluas sebesar $10 \%$.
\end{abstract}

Kata Kunci: Taksonomi SOLO, ujian nasional.

\section{PENDAHULUAN}

Pendidikan merupakan salah satu pondasi untuk kemajuan suatu bangsa. Semakin baik kualitas pendidikan dalam suatu bangsa, maka akan diikuti pula dengan baiknya kualitas sumber daya yang lain didalamnya. Sehingga upaya-upaya memperbaiki kualitas pendidikan perlu ditingkatkan dan menjadi tanggungjawab bersama. Salah satu upaya yang dapat dilakukan untuk memperbaiki kualitas pendidikan yaitu dengan cara menetapkan kurikulum yang digunakan, peningkatan kompetensi guru, perbaikan sarana prasarana dan lain-lain. Kegiatan memperbaiki kualitas pendidikan dilakukan oleh setiap negara dengan caranya masing-masing.

Selain diadakan perbaikan kualitas pendidikan, adapula suatu kegiatan yang berkaitan besar untuk mengukur kualitas pendidikan yaitu evaluasi. Menurut Arifin (2017) evaluasi 
merupakan suatu proses yang sistematis, berkelanjutan dan menyeluruh dalam upaya untuk meningkatkan, mengendalikan, serta menjamin kualitas pem-belajaran terhadap komponen pembelajaran berdasarkan pertimbangan dan syarat tertentu Evaluasi dalam pembelajaran menjadi hal penting dalam dunia pendidikan karena memiliki beberapa tujuan seperti yang dinyatakan dalam Undang-undang Republik Indonesia No. 20 tahun 2003 tentang sistem pendidikan nasional. Tujuan diadakannya evaluasi adalahh untuk memantau proses, kemajuan serta perbaikan pada kualitas pendidikan. Ada beberapa macam evaluasi yang digunakan dalam pembelajaran. Salah satu evaluasi pembelajaran yang dilakukan di Indonesia adalah ujian nasional.

Ujian nasional menurut Permendiknas No 5 tahun 2015 pasal 1, menyatakan bahwa ujian nasional atau yang selanjutnya di sebut UN adalah suatu kegiatan pengukuran dan penilaian pencapaian kompetensi lulusan secara nasional pada setiap jenjang pendidikan dan pada mata pelajaran tertentu. Menurut Arifin (2017), ada beberapa manfaat diadakan ujian nasional yaitu untuk mengendalikan mutu pendidikan, mengukur pencapaian peserta didik, serta sebagai bentuk pertanggungjawaban atas penyelengaraan pendidikan. Meskipun ujian nasional memiliki beberapa manfaat dan menjadi perhatian khusus pada setiap elemen yang ada di dalamnya akan tetapi proses pelaksanaanya masih terdapat beberapa kendala di dalamnya. Salah satu kendala yang terjadi di lapangan adalah mengeluhnya soal yang tertuang dalam ujian nasional yang berdampak pada hasil ujian nasional.

Salah satu alat yang dapat digunakan untuk melihat kualitas soal menurut Biggs dan Collis (Kuswana, 2012) adalah taksonomi SOLO. Taksonomi SOLO atau taksonomi struktur hasil belajar teramati adalah cara sisematis dalam menggambarkan kinerja pembelajaran dapat tmbuh mulai dari kompleksitas rendah sampai tingkat abstraksi. Dalam hal ini taksonomi SOLO mampu menggambarkan kualitas respon peserta didik. Selain itu, dapat juga digunakan untuk menilai kualitas tingkat soal.

\section{METODE}

Penelitian ini menggunakan penelitian kualitatif deskriptif. Penelitian kualitatif menurut Moloeng (2012), penelitian kualitatif adalah penelitian yang bertujuan untuk memahami fenomena-fenomena yang terjadi disekitar lingkungan peneliti yang dituangkan dalam bentuk deskripsi kata-kata dan bahasa dengan memanfaatkan berbagai macam metode alamiah. Pada penelitian tujuan mendeskripsikan tentang tingkatan soal ujian nasional matematika SMA tahun pelajaran 2018/2019 berdasarkan taksonomi SOLO. Sumber data yang digunakan adalah naskah ujian nasional matematika SMA tahun pelajaran 2018/2019 pada program IPA.

Pada tahap mengambil objek penelitian peneliti menggunakan teknik purposive sampling. Menurut Satori dan Komariah (2014) Purposive sampling adalah teknik pengumpulan subjek atau objek berdasarkan kebutuhan. Pada penelitian ini banyak soal yang diambil adalah 20 soal dari jumlah soal yang tersedia dalam satu paket ujian nasional adalah 40 soal. Teknik pengumpulan data yang digunakan yaitu teknik dokumentasi yang selanjutnya dianalisis masing-masing soalnya kemudian dikelompokan berdasarkan taksonomi SOLO. Untuk teknik analisis data yang digunakan pada penelitian ini yaitu teknik analisis data menurut Miles dan Huberman yang meliputi reduksi data, penyajian data dan penarikan kesimpulan.

\section{HASIL DAN PEMBAHASAN}

Pada bagian pembahasan ini, peneliti akan menjelaskan mengenai temuan di lapangan dan data analisis soal ujian nasional matematika SMA tahun pelajaran 2018/2019 berdasarkan taksonomi SOLO. Pada soal tersebut memuat ke empat tingkatan pertanyaan yaitu unistruktural, multistruktural, relasional dan abstrak diperluas. Pada tingkat unistruktural (U) 
memuat beberapa macam kata kerja yang beragam untuk setiap butir soalnya. Sebuah satu soal yang di kategorikan pada tingkat unistruktural itu artinya soal tersebut memiliki ciri bahwa pada soal sudah terdapat informasi yang jelas untuk dapat digunakan secara langsung. Dari 20 soal yang diteliti terdapat 1 atau $5 \%$ dari total soal yang diteliti masuk ke dalam kategori tingkat unistruktural. Berikut adalah soal yang termasuk ke dalam tingkat unistruktural:

$$
\begin{aligned}
& \text { 21. } \int\left(3 x^{2}-5 x+4\right) d x=\ldots \\
& \begin{array}{ll}
\text { A. } x^{3}-\frac{5}{2} x^{2}+4 x+C & \text { D. } 6 x^{3}-5 x^{2}+4 x+C \\
\text { B. } x^{3}-5 x^{2}+4 x+C & \text { E. } 6 x^{3}-\frac{5}{2} x^{2}+4 x+C \\
\text { C. } 3 x^{3}-5 x^{2}+4 x+C &
\end{array}
\end{aligned}
$$

\section{Gambar 1. Soal Unistruktural}

Soal pada gambar 1 terdapat perintah supaya peserta didik mampu menentukan hasil suatu integral. Apabila peserta didik mampu mengingat kembali rumus dasar integral serta sifat-sifat integral maka siswa akan mampu menemukan jawaban dari per-tanyaan tersebut. Berdasarkan perintah soal yang langsung bisa dikerjakan tersebutlah maka soal pada gambar 1 termasuk ke dalam tingkat unistruktural.

Selanjutnya pada tingkat multistruktural (M) kriteria soal tidak berbeda jauh dengan tingkat unistrukural. Pada soal yang dapat dikatakan kategori multistruktural adalah sebuah soal yang memiliki dua informasi akan tetapi informasi tersebut perlu dihubungkan sehingga mampu untuk menyelesaikan soal tersebut. Jumlah soal yang masuk kategori multistruktural adalah 2 atau 10\% dari total soal yang diteliti. Berikut merupakan contoh soal yang termasuk kategori tingkat multistruktural:

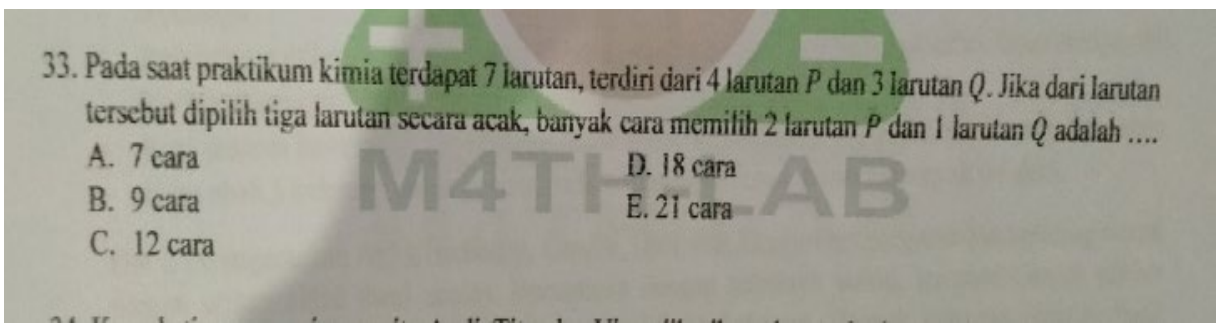

Gambar 2. Soal Multistruktural

Soal pada gambar 2 terdapat perintah supaya peserta didik mampu mengerjakan soal yang berkaitan dengan materi kombinasi suatu kejadian. Informasi yang dibutuhkan untuk menyelesaikan soal sudah tersedia akan tetapi peserta didik harus mampu mengklasifikasikan atau menghubungkan bagian-bagian informasi tersebut supaya soal tersebut dapat ditemukan hasilnya. Berdasarkan perintah soal yang di dalam pengerjaanya meminta siswa untuk menghubungkan informasi tersebut maka soal pada gambar 2 termasuk ke dalam tingkat multistruktural.

Kemudian pada tingkat relasional (R) kriteria soal yang dapat dikategorikan ke dalam tingkat relasional adalah soal yang memilik ciri bahwa pada soal tersebut memiliki dua informasi yang tidak dapat langsung digunakan, sehingga perlu menemukan informasi baru. Dari informasi baru tersebut nantinya akan digunakan untuk menyelesaikan soal tersebut. Jumlah soal yang termasuk pada kategori relasional berjumlah 15 atau $75 \%$ dari jumlah soal yang diteliti. Berikut merupakan contoh soal yang termasuk kategori relasional: 


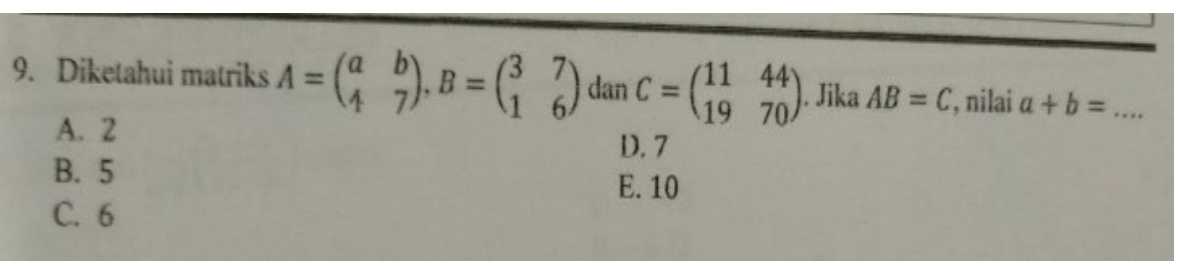

Gambar 3. Soal Relasional

Soal pada gambar 3 meminta siswa untu mampu menyelesaikan soal yang berkaitan dengan perkalian matriks. Pada soal tersebut soal tidak bisa langsung menemukan hasil nilai penjumlahan dari $a+b$. Untuk menemukan hasil tersebut siswa harus mampu menemukan informasi baru yaitu berapa nilai yang mewakili masing-masing nilai $a$ dan $b$. Pada proses menemukan nilai yang mewakili tersebut siswa diminta untuk mampu mengingat kembali rumus perkalian matriks serta sifat-sifat pada operasi matriks. Berdasarkan penjelasan tersebut-lah maka, soal gambar 3 termasuk kedalam tingkat relasional.

Tingkat selanjutnya yaitu tingkat abstrak diperluas. Kriteria soal yang masuk kedalam tingkat abstrak diperluas yaitu soal yang memilik informasi lebih dari dua soal, perlu adanya informasi baru yang dilakukan melalui prinsip umum abstrak atau hipotesis untuk mengaitkan informasi yang ada kedalam situasi baru dan lebih abstrak. Jumlah soal yang masuk ke dalam kategori abstrak diperluas berjumlah 2 atau $10 \%$ dari jumlah soal yang diteliti. Berikut merupakan salah satu contoh soal yang masuk ke dalam kategori abstrak diperluas:

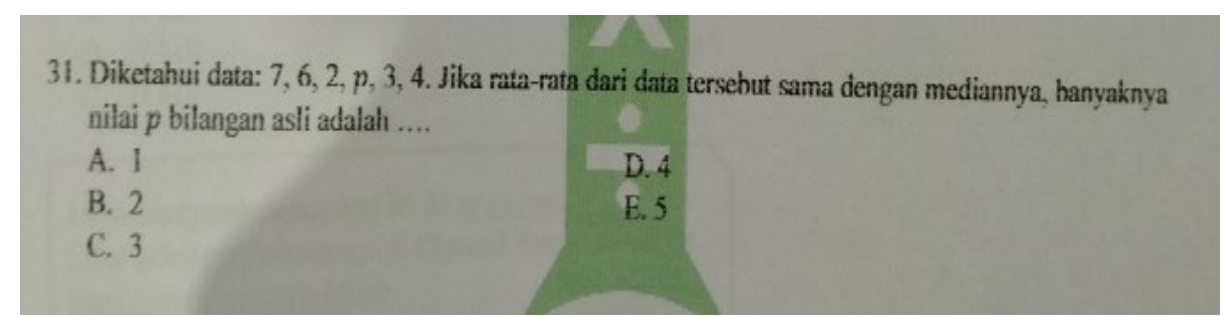

Gambar 4. Soal Abstrak Diperluas

Soal pada gambar 4, merupakan jenis soal abstrak diperluas dikarenakan dalam proses pengerjaanya peserta didik diminta untuk mampu membuat suatu kemungkinan jawaban yang akan terjadi atau suatu hipotesi atau dugaan sementara jawaban. Selain itu, peserta didik juga diminta untuk mampu membuat beberapa macam kemungkinan kejadian dari data tersebut sehingga menjadi beberapa kelompok data yang didasarkan pada rata-rata yang sama nantinya digabung menjadi satu.

\section{KESIMPULAN}

Berdasarkan hasil penelitian dan pembahasan yang peneliti lakukan dapat disimpulkan bahwa soal ujian nasional matematika SMA tahun pelajara 2018/2019 memiliki ke empat tingkatan pada tingkat pertanyaan berdasarkan taksonomi SOLO. Presentasi ke empat tigkatan berdasarkan taksonomi SOLO yang meliputi unistruktural, multistruktural, relasional, dan abstrak diperluas berturut-turut adalah 5\%, 10\%, 75\% dan 10\%.

\section{DAFTAR PUSTAKA}

Arifin, Zainal. 2017. Evaluasi Pembelajaran. Bandung: PT Remaja Rosdakarya Kuswana, Wowo Sunaryo. 2012. Taksonomi Kognitif. Bandung: PT Remaja Rosdakarya Moleong, L. J. 2012. Metodologi Penelitian Kualitatif. Bandung: PT Rosdakarya Peraturan Menteri Pendidikan Nasional No. 5 tahun 2015 Tentang Kriteria Kelulusan Peserta Dididk Penyelenggaraan Ujian Nasional dan Penyelenggaraan Ujian Sekolah/ 
Madrasah/Pendidikan Kesetaraan Pada SMP/MTS atau yang Sederajat dan SMA/MA/ SMK atau yang sederajat

Satori, D. dan Aan Komariah. 2014. Metode Penelitian Kualitatif. Bandung: Alfabeta Undang-undang No. 20 tahun 2003 Tentang Sistem Pendidikan Nasional. Jakarta 